\title{
Entrepreneurial city in Russian economy: quantitative and qualitative parameters of identification
}

\author{
Irina Baskakova, and Olga Suldina* \\ UrFU named after the First President of Russia B.N. Eltsin, 620075 Yekaterinburg, Russia
}

\begin{abstract}
This paper is devoted to research the "entrepreneurial city" in Russian economy. Firstly the authors analyze the development of the concept in foreign studies and compare the results with Russian authors researches. This concept is not so widespread both in scientific sphere and in municipal level in Russia. Then the authors propose two groups of parameters that give the opportunity to identify entrepreneurial city using Russian statistics. From the one hand there are quantitative parameters that include the degree of economic diversity and services; presence of human capital; the degree of the urban environment and living conditions. Each of criteria was evaluated on the several statistic indicators. From the other hand there are qualitative parameters that help to explain differences between similar cities. For example, the authors consider two close Ural cities, Chelyabinsk and Yekaterinburg, and analyze its differences according quantitative and qualitative criteria of entrepreneurial city.
\end{abstract}

\section{Introduction}

In recent years there has been a sharp increase of interest in spatial development both in the country's management sphere and among economists. The creation of the spatial development strategy for Russia until 2025, the preparation of "Smart cities" pilot project, the project of agglomeration creation, the numerous urban forums are all part of a big Russian task to find new trajectories for regional growth and development.

Using of entrepreneurial city concept in modern conditions can open new ways of development. At the first managerial tools within this concept has produced good results in different countries of the world and at the second any city can become an entrepreneurial, despite of the size and initial amount of resources. The latter is especially important for Russia, with its huge number of small cities and a huge gap in their ability to manoeuvre, compared to the capital cities.

We see the aim of our work as an attempt to find "entrepreneurial city" in Russia. For this purpose we consider the differences in concept in foreign and Russian economic studies, define the quantitative criteria of its identification and to consider the influence of qualitative parameters in relation to Chelyabinsk and Yekaterinburg.

\footnotetext{
*Corresponding author: olgasuld@gmail.com
} 


\section{The emergence and development of the entrepreneurial city concept (materials and methods)}

The beginning of an active study of the "entrepreneurial cities" was initiated by D. Harvey in 1989.[1] He analyzed the changes that had taken place in the activities of city governments and noted that in conditions of significant political and economic instability, local authorities had been looking for new ways to stimulate the development of territories and increase employment. This entrepreneurial focus differed from the previously prevailing style of urban governance, which was mainly aimed at providing local social services to the population. The author also paid attention to the increasing competition between cities and, as a result, the change in the managerial model of local government: from managerialism to an active entrepreneurial position.

In foreign tradition the entrepreneurial city is characterized by the presence of the implemented innovation strategy and functional institutional structure, the main task of which is to create conditions for maximum attraction of mobile financial, production and consumer flows.[2] As the main characteristics of the entrepreneurial city, foreign authors emphasize the large-scale projects on the basis of public-private partnership to promote the territory, the risks of such projects can be covered with the use of public resources and the effect of their implementation can affect an area larger than the city.[1]

Therefore, calling cities as entrepreneurial, the authors do not mean the ability of the urban community to "do business", they mean the ability of local authorities to act, "take" new steps to improve the internal institutional environment that contributes to long-term sustainable growth and development of the city's economy (see, for example, [3]). Entrepreneurial cities work purposefully on their image in order to become attractive for business [4] and for highly qualified specialists - "creative class" [5].

Table 1. Main characteristics of entrepreneurial city in foreign authors studies

\begin{tabular}{|c|c|}
\hline Main characteristics of entrepreneurial city & Author \\
\hline $\begin{array}{c}\text { Public-private projects } \\
\text { Risk distribution between government and business in such projects } \\
\text { The effectiveness of the projects extend to the territory more than } \\
\text { this city }\end{array}$ & D. Harvey \\
\hline $\begin{array}{c}\text { Real innovative strategy } \\
\text { Entrepreneurial discourse of city officials in media } \\
\text { Strong mayor }\end{array}$ & B. Jessop and N.L. Sum \\
The ability of urban community to self-organize & \\
\hline $\begin{array}{c}\text { Large infrastructure projects, redevelopment projects and } \\
\text { renovation of industrial zones }\end{array}$ & $\begin{array}{c}\text { S. Clarke and G. Gaile; } \\
\text { G. MacLeod }\end{array}$ \\
\hline $\begin{array}{c}\text { The authorities contribute: } \\
\text { the growth of economic diversity, the development of human } \\
\text { capital, the expansion of institutional networks, the improvement of } \\
\text { the urban environment and living conditions }\end{array}$ & M. Parkinson \\
\hline
\end{tabular}

In the studies of Russian scientists the "entrepreneurial city" concept is actively used, but, as a rule, without specifying the content.[6] In addition, there are no clear criteria for determining which city is an entrepreneurial. In Russia, the main source of entrepreneurial practices distribution is the local government, interested in the development of the territory, which has the trust of business and the population. A number of institutional barriers [7] prevent the spread of the "entrepreneurial city" concept in practice. However, the management staff of the most active cities are trying to realize the entrepreneurial practices, despite the limitations and exceptional heterogeneity of the Russian economic space.[8] 


\section{Quantitative parameters of entrepreneurial city identification in Russia (results and discussion)}

First, let's clarify the principles of sample for Russian cities research. The Federal State Statistics Service publishes information about Russian cities every two years in special edition "Regions of Russia. The main social and economic indicators of cities". This sample includes all cities that have the regional capital status and also cities that are not the administrative center of their region, but have a population of more than 100 thousand inhabitants.

According to numerous researchers, active cities compete with each other for attracting investment and population (see, for example, [9]), so we will search entrepreneurial cities among the cities that work most effectively in both directions. For clarity, we present results graphically (fig. 1).

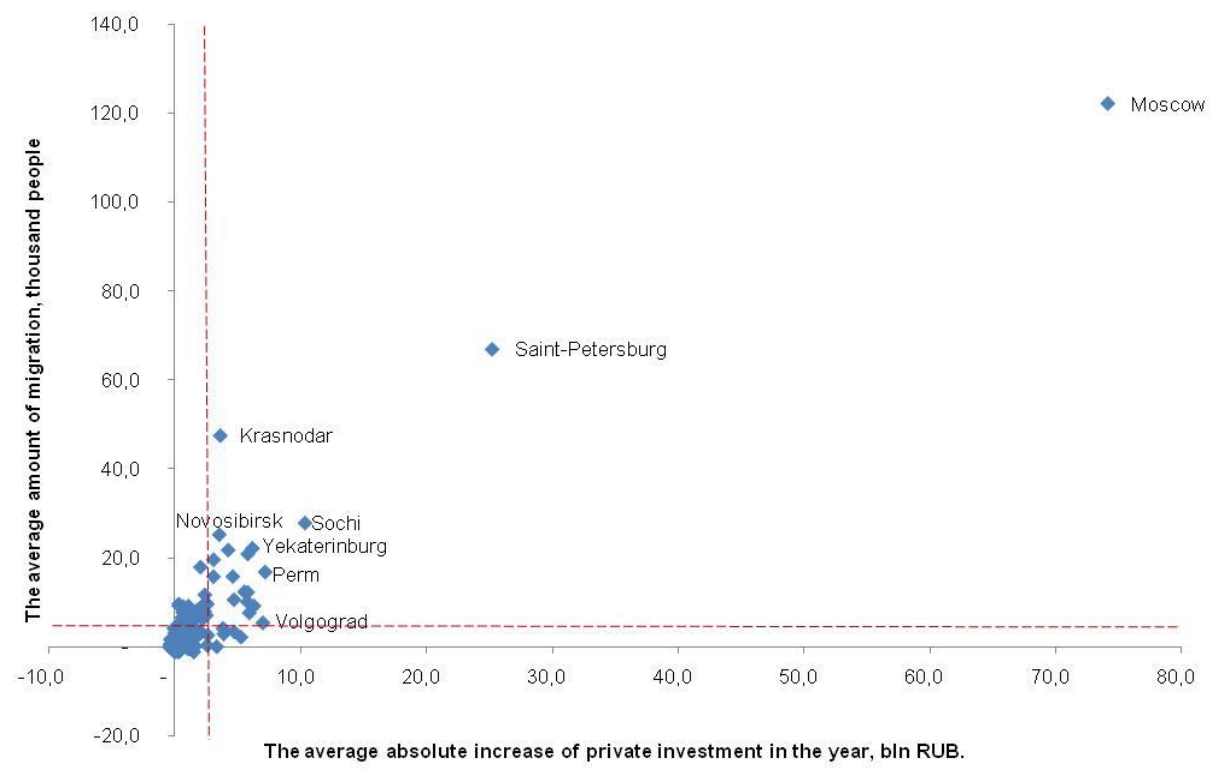

Fig. 1. Cities compete to attract investment and people

On the horizontal axis, there is an average absolute growth of private investment per year, showing how much the volume of private investment in Russian cities grew annually from 2002 to 2015 . The vertical dotted line is held at the level of the average value -1.79 billion rubles per year. Private investment is more sensitive to various institutional factors and administrative measures than budgetary ones. The average amount of migration growth along the vertical axis determines which cities are the most attractive for the population. The average value of the horizontal line is 5.3 thousand people per year. More than half of the cities (139 out of 164) show positive migration population growth from 2010 to 2015 .

According to the objectives of the study we are interested in 28 cities located in the first quadrant, bordered by dotted lines: Astrakhan, Vladivostok, Volgograd, Voronezh, Yekaterinburg, Kazan, Kaluga, Krasnodar, Krasnoyarsk, Moscow, Nizhnevartovsk, Nizhnekamsk, Nizhny Novgorod, Novosibirsk, Omsk, Perm, Rostov-on-don, Samara, St. Petersburg, Saratov, Sochi, Surgut, Tomsk, Tyumen, Ufa, Khabarovsk, Chelyabinsk, Yakutsk.

In our first work [10] we used the following parameters to identify among them the cities with the greatest entrepreneurial potential: 1) the degree of economic diversity and 
services; 2) the presence of human capital; 3) the degree of the urban environment and living conditions. Due to the limitations of statistical accounting in Russia, several indicators will evaluate each of them:

- the increase in the number of enterprises and organizations above the national average, the growth of retail trade turnover per capita above the national average (rubles), the growth of catering turnover per capita above the national average (rubles) (to understand the level of economic diversity and services);

- the average number of doctors per 10000 population higher than the national average (to understand availability of human capital);

- the average total area of residential premises per 1 inhabitant of the city above the national average, the increase in the number of registered crimes per 1000 people is below the national average (to understand the quality of the urban environment and living conditions).

Because of the quantitative analysis, 6 Russian cities from the first quadrant were identified as entrepreneurial, the activities of their leadership are most consistent with the entrepreneurial city concept: Samara, Yekaterinburg, Kazan, Krasnodar, St. Petersburg and Tyumen. They are characterized by a positive migration growth of the population and an increase in private investment in fixed assets above the average Russian level, as well as a developed service sector, the availability of human capital and good living conditions for people.

Now let us consider in more detail the situation in the cities of the Ural Federal District, especially Yekaterinburg and Chelyabinsk (fig. 2). We chose these cities because of their similarity: the same district, the same administrative status, the close number of population (more than a bln), a lot of manufactures in economic structure. Moreover these two cities will be include into deep agglomeration process according to national economic recovery plan.

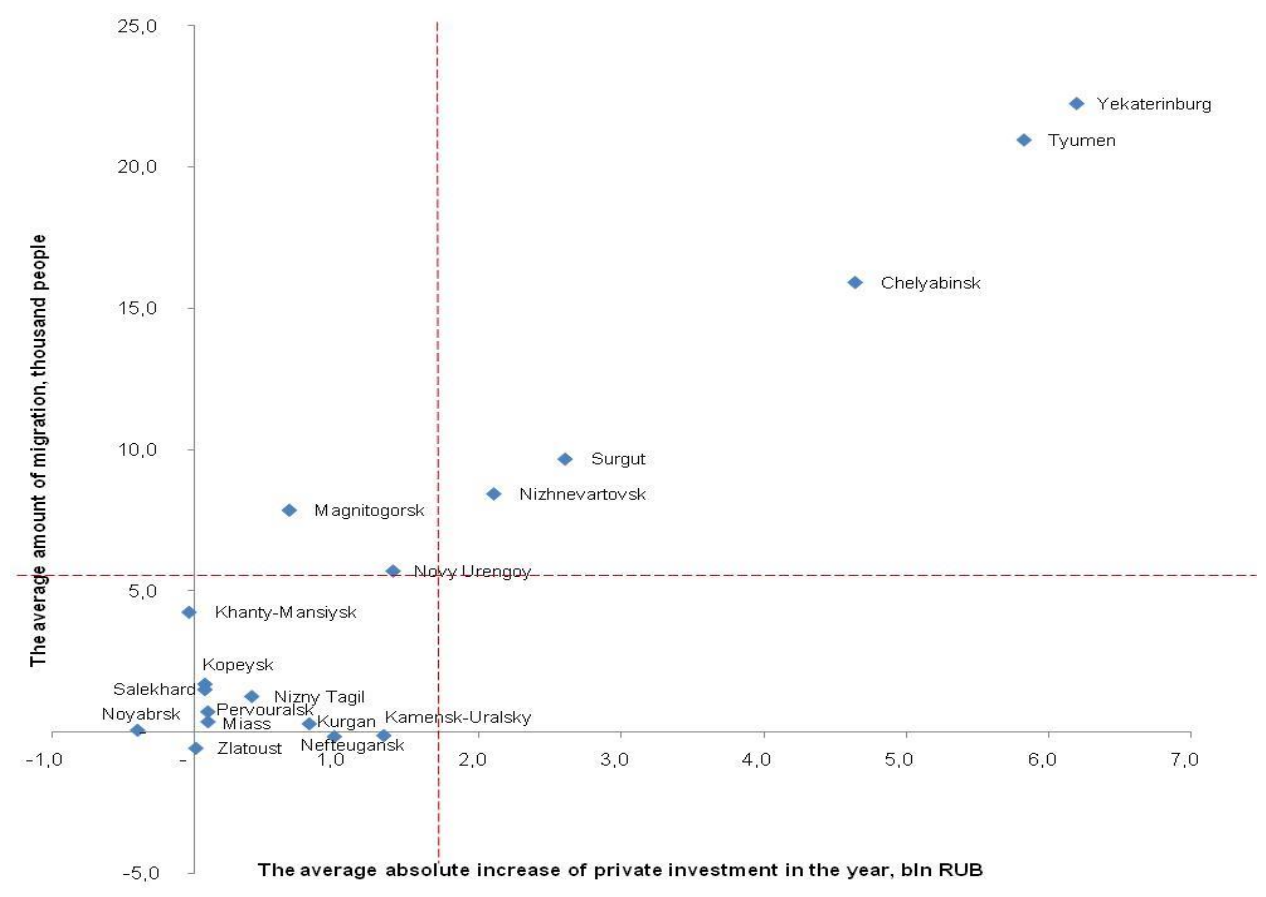

Fig. 2. Cities in Ural Federal District 
But despite of similarity, we see that Yekaterinburg and Chelyabinsk differ in terms of attracting investment and human capital in favor of the first.

We will test the situation in the Ural megacities for the presence of qualitative parameters - characteristics of the entrepreneurial city which were allocated from foreign studies.

1. Availability of public-private partnership projects. In the ranking of Russian regions in terms of PPP development in 2018, Sverdlovsk region (Yekaterinburg is the main city of this region) takes the 14th place, Chelyabinsk region - the 17th.

2. Availability of a working innovation strategy. In 2003, a Strategic plan for the development of Yekaterinburg until 2020 was adopted, the main goal of which was to change the city of heavy industry into a multifunctional megapolis. Most of the tasks were implemented by the end of the first decade. In 2010, the plan was revised, and the emphasis in the development of the city shifted towards integration into the world economy and the creation of a comfortable living environment. [11] Yekaterinburg tries to get major international events (World Cup, Innoprom, SCO summit, World congress of people with disabilities etc.).)

In Chelyabinsk, there was a Strategy for the city development until 2020, but at this moment new Strategy until 2035 is being actively developed, marketing activities that can improve the image of the territory are being actively discussed, the city was preparing for the SCO and BRICS summits in 2020.

3. Entrepreneurial discourse of the city leadership in the media. According to Jessop and Sum [2], an important feature of entrepreneurial city is the presence of entrepreneurial discourse in the speech of officials. Now there is no desire to position both Yekaterinburg and Chelyabinsk as entrepreneurial city among representatives of government and business. This situation is most likely due to the fact that this term has not yet taken root in the Russian information field and is used mainly in the scientific community.

4. Availability of large infrastructure projects, redevelopment projects and renovation of industrial zones. A major infrastructure project to Chelyabinsk and Yekaterinburg both is the construction of a high-speed highway.

The administration of Yekaterinburg supports the removal of enterprises from the city center and the renovation of industrial areas. Thus, in 2013 the Yekaterinburg flour milling plant was moved outside the city, and in its place the UMMC company is building an elite "Makarovsky district". Now there is the large-scale project of renovation of the former Uralplastic plant territory and construction on its place "Zavokzalny district" by "PIK" company. In Chelyabinsk, the situation with the removal of enterprises outside the city is characterized by local authorities as "fantastic"[12].

5. The ability of the urban community to self-organize. In open sources it was repeatedly noted that Yekaterinburg is a city with an active civil position, and its population is distinguished by activity and entrepreneurship. [11] Public hearings on socially significant issues are regularly held in Yekaterinburg, business forums are organized with the participation of representatives of business and government. In Chelyabinsk media meetings of the authorities and the city community are also actively discussed, but as the result of the heavy industry structure of the city economy is a social imbalance in favor of factory workers, and they are not the white collars.

Thus, having considered the situation in Yekaterinburg and Chelyabinsk according to qualitative criteria of the entrepreneurial city concept, we can conclude that the leading position of Yekaterinburg explained by the presence of really working innovation city strategy, which does not change with the advent of the new government, as well as in the greater number of the initiative urban population. 


\section{Conclusion}

In the conditions of global instability and reduction of revenues from the federal and regional budgets, Russian cities need to find independent ways out of the crisis. One of these ways can be the development of entrepreneurial skills of municipal officials and the introduction of successful practices of entrepreneurial city. The applied orientation of this concept and practical significance for the design of development strategies, including problem cities, makes it important to understand the criteria for their recognition.

The authors of the study tried to consider the situation in Russia, we identified 6 cities as entrepreneurial using quantitative parameters and then tried to explain the differences of very close cities Chelyabinsk and Yekaterinburg, taking into account quantitative and qualitative criteria of entrepreneurial city identification. According to entrepreneurial city concept municipal officials of Chelyabinsk should be more attentive to realization of city innovation strategy and to keep it despite of the city management changes. And also they should develop and encourage the initiative urban community.

\section{References}

1. D. Harvey, Geografiska Annaler: Series B, Human Geography, 71, 3 (1989)

2. B. Jessop, N. L. Sum, Urb. St., 37, 2287 (2000)

3. T. Hall, P. Hubbard, Progress in Human Geography, 20, 153 (1996)

4. S. Roberts, R. Schein, NY Prof. Geo., 45, 21 (1993)

5. R. Florida, The Rise of the Creative Class: And how It's Transforming Work, Leisure, Community and Everyday Life (2002)

6. S. Vazhenin, V. Bersenev, I. Vazhenina, A. Tatarkin, Territorial competition in the economic space (2011)

7. I. Baskakova, O. Suldina, UrFU GSEM, Conf. Proceedings, 13, 206 (2019), https://www.elibrary.ru/

8. I. Baskakova, O. Suldina, I. Turgel, L. Bozhko, SGEM, Conf. Proceedings, 5, 129 (2018), https://www.elibrary.ru/

9. N. Shapiro, I. Kaplina, E. Nikolaeva, S. J. NRU ITMO, Series Eco. and Env. Man., 4 (2013)

10. I. Baskakova, O. Suldina, Bulletin of Urfu. Series Economy and Management, 16, 597 (2017), https://www.elibrary.ru/

11. Yekaterinburg strategic development plan, https://екатеринбург.pф/

12. O. Goruk, Chel. MK-Ural, 20.12 (2018) 